\title{
The security problem in the Gulf Cooperation Council countries Study on internal challenges and future prospects
}

\author{
Dr Ammar Hameed Yasein ${ }^{*}$ \\ Assistant Professor College of Political Science, University of Baghdad research field: international studies. Al - Jadriya Complex, Baghdad, Iraq
}

Received 10 April 2019, Accepted 12 June 2019, Available online 13 June 2019, Vol.7 (May/June 2019 issue)

\begin{abstract}
The importance of our research is that it examines the causes and sources of the security challenges in the internal security environment of the GCC countries, and aims to address the most important issues that are of great interest, namely, the issue of inter-GCC differences and addressing the issues of regional security for the Gulf region, After it is one of the most dynamic and more polarized areas for the emergence of threats and challenges because of the multiplicity of sources of threat and their complexity due to the specificity of the strategic environment and the negative repercussions it can have on the Gulf region, especially the issue of regional security of the Gulf Cooperation Council Which has become a magnet for competing international and regional powers to preserve their interests and ensure the achievement of their objectives. This has further complicated the internal security environment in the Gulf, especially the recent events represented by a package of measures taken by Saudi Arabia, the UAE and Bahrain. As well as Egypt against Qatar, have begun to reveal to us the depth and root of differences, the size of internal challenges and the weakness of the ability of the GCC countries to meet their obligations in laying the foundations of a joint securitydefense system with the capacity to face these challenges collectively, Security challenges are therefore not only external regional or international, but internal with inter-GCC interface
\end{abstract}

Keywords: Security problem, Gulf Cooperation Council countries internal challenges future prospects

\section{Introduction}

The Gulf Cooperation Council (GCC) countries have undergone an unprecedented security transition, so what the region witnessed as a result of the aftermath of the three wars, as well as the events of 11 September 2001, was a radical change in its geostrategic environment and transformations at the political, economic, social and military-security levels. The most prominent manifestation of this shift is the tendency to directly employ military force in the region, embodied by the occupation of Iraq in 2003, and Iraq's exit from the regional security equation.

As well as the region's countries are subjected to a series of pressure methods to join the system of war against terrorism, and to carry out internal reforms, and not only the issue, but the region is witnessing today's sectarian wars and proxy, and the competition for influence and hegemony and enter the framework of testing Are all internal challenges if they are not managed and provided with the necessary solutions through regional security arrangements that may represent real

*Corresponding author's ORCID ID: 0000-0000-0000-0000 DOI: https://doi.org/10.14741/ijmcr/v.7.3.15 responses to these internal challenges that threaten the security of the GCC countries.

Therefore, it was necessary to stand up to the most important concepts of security and its basic levels, which affected the level of the internal Gulf environment. On the other hand, the issue of regional security, although it has been discussed for a long time, but the new changes in the level of external and internal environments, After the events of 11 September 2001, the events of change in the Arab region in 2011 contributed to the production of threats and challenges at the level of the internal environment of the Gulf

Therefore, the problem of our research is based on the idea that: The security problem in the GCC countries is the weakness of its ability to determine the real response to face the internal challenges as a result of differences and divergences in the visions and perceptions between the countries, resulting in the emergence of indicators of negative responses to the challenges The interior facing the state.

Hence, the hypothesis of the research is that whenever there are consensus and common visions of a unified nature towards the challenges faced by the GCC countries, there were incentives to emerge positive response to these internal challenges and vice versa. 
In light of this, our research will be divided into three main topics

The first topic: The theoretical and conceptual framework of concept security - the levels

The second topic: internal challenges affecting the security of the GCC countries

The third topic: A future vision for the security of the GCC countries

1. The first topic: The theoretical and conceptual framework of concept security - the levels

The concept of security is a complex concept of its simplicity of expression and ambiguity when applied in the context of international politics

The concept of security is a changing reality that is characterized by the change resulting from many internal and external factors and conditions, as well as from complex concepts. It combines in its contents several meanings that are ambiguous and clear at the same time (1)

Security is a relative fact; its absolute guarantee cannot be achieved; it depends on internal and external variables

So we will study this subject according to two basic requirements

\section{The first requirement: the concept of security}

First, the limited concept is the procedure for insuring individuals within the State against potential dangers and creating the conditions for satisfying their basic needs, and the other, the broad concept that encompasses everything that achieves the political independence and territorial integrity of the State and ensures political, economic and social stability ( 2 )

Robert McNamara defined security as security: development, not military power, even though it is part of it. Security is not military activity, although it is part of it. Security means development, development and without development, we cannot talk about security

Arnold Wolfers defined security as an objective point of view: there is no threat to acquired values, and from a subjective point of view, there are no fears that these values are at risk

Accordingly, the external military threat is one of the priorities of the main strategy of the state security, and thus resorting to the use of the option of self-security to defend its interests by means of controlling and employing force, which is the essence of the security policy of the countries. And in the military dimension as a sector of analysis (3)

Within this context, those with a realistic view of security believe that it is necessary to identify the military, actual and potential threats facing the state and to assess the military capabilities of the state in order to confront these threats. The realist theory can analyze several levels. On the one hand, The six Gulf Cooperation
Council (GCC), Iran and Iraq, the interactions between the six countries and Iran were based on a rivalry and conflict between them, so the region witnessed three devastating wars that greatly affected the stability of the Gulf region (4)

Consistent with this, security is formulated in light of four basic pillars

Recognize the threats emanating from the strategic environment

-Draw a strategy for the development and development of state forces

-To provide the ability to face external and internal threats by building armed forces capable of confronting these threats

-Prepare scenarios and take action to address the threats that fit them.

The second requirement: Security levels ( 5)

That security can have several levels, such as international security, national security and regional security, through which we can employ regional security as the most important link in our research, especially as we focus on studying the security problem in the GCC countries, Regional security and regional security, although regional security is the result of local interactions between the parties to the region (6)

It is inseparable from international security and its fundamental interactions, especially in a region where the strategic interests of the international parties are the focus of attention of the major powers. Especially that there are regions that affect international security and others are affected by changes in the nature of perceptions related to the concept of security and levels, and considers that the Arab Gulf region is the subject of our research a clear example and a formula for effective regional security intertwined with international security (7)

International security is the broad and comprehensive security level that is the sum and total security of each Member State of the international environment. This level is affected by the relationship of the state with other countries, especially the major, and the formula of strategic alliances on issues of conflict and international competition, The contribution of the State to the achievement of international security and its participation in international conferences and the constraints imposed by the system of collective security accepted by the State within the international community (8)

In the same context, regional security is defined as a set of coordinated and integrated policies for a group of countries in a single region, with common characteristics of cooperation between them. The foundations of any regional security can be mentioned as follows :

To promote cooperation and integration among the countries of the Region at different levels 
To create conditions for the development of interregional relations among the countries of the Region in all fields

Commitment to the basic objectives of any regional system

Therefore, the establishment of a regional security system requires the availability of a set of basic elements

The realization of these regional units is the high cost of open-ended conflicts

Accepting the idea of developing the security system in such a way as to express different visions regarding regional and international issues

Therefore, stability in any region should be based on regional consensus and cooperation, not reliance on bilateral relations

This reinforces the motivation for the establishment of a regional security system with security roles based on compatibility and cooperation within the framework of future regional subsystems (9)

The second topic: internal challenges affecting the security of the GCC countries 2. 1

The Gulf Cooperation Council (GCC) faces many internal challenges with political, economic, social and military-security implications, which have greatly affected the achievement of the goals for which it was founded. This has created a set of constraints to its effective influence within the regional framework

Therefore, the GCC countries realized that the challenges they faced were forced to find formulas for cooperation and common understandings in order to confront and respond to them by establishing a system of collective action. This system is a means of rapprochement and cooperation among their peoples. Common

The Gulf Cooperation Council (GCC) was established in 1981 in response to the challenges it faces collectively as a result of the security changes that have taken place in the Gulf region. Three wars have been witnessed, as well as the repercussions of the events of 11 September 2001 and its changes in the geopolitical environment of the region. , Characterized by the features of that shift by the tendency of direct military intervention in the region, which is the occupation of Iraq in 2003 and its departure from the balance of regional security equation, as well as the exposure of the countries of the region

To pressures with political and economic implications for joining the US strategy of the war against terrorism The rise in the demand for political participation, the decline in oil prices and the growing levels of organized crime are all challenges that will affect and extend their impact if they are not addressed and managed by the presence of Security arrangements at regional levels may represent real responses to these problems and challenges between the GCC regional system units.

The most important challenges with the political implications of the GCC countries have been the challenge of identity. The identity of the Gulf Cooperation Council (GCC) remains ambiguous. Why, the answer is centered around three basic points
The Charter The Council has not been well defined (10)

-The circumstances of its inception hampered its development, especially as the security formula that has emerged has dominated the nature of its interactions and relations between the Gulf Cooperation Council countries

The general formulations that overshadowed most of its objectives

The Statute did not refer in any of its clauses to what is the GCC. Is it a political function that moves from coordination and cooperation to integration or a security gathering formed because of the nature of the situations that coincided with Its establishment or economic integration, it is this omission to determine the nature of the Council which contributed to the ambiguity of the nature of the Council and its objectives(11)

In line with this, a number of conceptions emerged about the purpose of its establishment, the first of its economic dimensions adopted by Kuwait. It focused on the priority of the economic and social dimensions from the idea of the possibility of strengthening cooperation between the GCC countries in order to promote it to characterize the common Gulf market

The second scenario adopted by the Sultanate of Oman was of a military nature, since the Council must be a military alliance directed against specific enemies, as well as the possibility of involving international parties outside the Gulf regional system

The third scenario adopted by Saudi Arabia was based on a political vision: how to achieve political coordination and enhance collective security perceptions without including an excess of the sovereignty of the Member States (12)

The other challenge facing the GCC countries can be described under the so-called institutional immaturity, which can be felt by knowing that the Council does not have as an independent entity powers to activate the decisions necessary to carry out its tasks and to stimulate the rapid response component to meet the challenges and the ability to issue binding legislation to Member States through which the institutional work can be upgraded within the framework of the Gulf Cooperation Council, and the GCC is not independent in external decision-making

Especially if we know that the biggest imbalance is concentrated in the non-activation of decisions taken by the Supreme Council of the Gulf Cooperation Council, as a result of immaturity of the executive structure of the GCC, since the executive powers are concentrated in it, but an entity is independent of the will of the founding States

Opportunities for transition to democratic governance in the GCC are a challenge at the level of the Gulf's internal environment. All GCC states are known to have genetic systems. The power is monopolized by families, and has the ultimate right to make important decisions and to act. In the wealth of society, and this represents 
the most important internal challenges because of the specificity of these countries, especially as they are linked to political systems based on shura and the provisions of Islamic law

Especially that the traditional values based on patriarchy and subordination to the ruling families are still present to this day, and continuity continues to take precedence over the status of the criterion of efficiency, as well as that some of the ruling families began a path not based on full partnership with their people, A mandate from their own people, but the government has become closer to the booty (13)

GCC regimes continue to rely mainly on alliances and tribal balances within the ruling family and some tribal forces allied to some religious currents. This has weakened political loyalty and national belonging. Citizens have begun to define their relationship to the state not by means of inputs Established citizenship but through tribal relations with narrow traditional frameworks

Because of the above, we can see that there is a clear discrimination on several levels of sectarian, sectarian, sectarian, and regional, because they are still in the state sponsor and did not move into the role of partnership. The relationship between states and their citizens is based on the fact that they are nationals not partners. The GCC has not moved from the tribal state to the modern state with its modern elements based on the criteria of competence and qualifications rather than personal allegiance.

Here we believe that the aspect of promoting citizenship rather than the idea of parish should be highlighted. But this requires social transformations that will move the Gulf society from the stage of relying on the links of tribal affiliation to the stage of relying on civil rights and citizenship (14)

As for constitutions, although these systems have constitutions or legal systems, there is a great difference in their degree of development and political values. In terms of their characterization or application of the principle of popular participation in power, the principle of separation of powers and protection of fundamental rights and freedoms varies. Constitutions, except the constitutions of Kuwait and Qatar, have been issued in the form of the grant. This indicates that these constitutions and political systems seek to strengthen the legitimacy of the ruling families and institutionalize them. But emphasizes the principle of consultation as the basic pillar of governance, as well as the need to establish councils, but they differ from one constitution to another regarding the legislative and regulatory powers, and the degree of popular participation in how it is formed and elected

In Kuwait and Bahrain, the constitution provides for the formation of an elected legislative council based on the two-chamber system. In the United Arab Emirates, the constitution provides for the establishment of an advisory council half of which is appointed and the other half elected. In Oman, there are two chambers, one elected and the other appointed. In spite of the fact that these constitutions and regulations provide for the principle of separation of powers, they give the governor broad executive, legislative and judicial powers, which indicates that there are no similar constitutions due to differences in the perception of the level of democratic transition The part on the other hand, the regimes of the GCC countries are characterized by a lack of political openness, which leads to the absence of political participation, which in turn stimulates the possibility of popular protests similar to the events of change witnessed in the Arab region in 2011

As well as the lack of common perceptions among the decision-makers in the Gulf region regarding the nature of the challenges, obstacles and threats facing them, and this may lead to the emergence of internal conflicts between the GCC countries, as happened with Qatar on the one hand, Saudi Arabia, Bahrain and the Emirates on the other (15)

As for the most important economic challenges facing the GCC countries is that it suffers from the issue of economic exposure, because of the lack of diversification in economic structures, as well as dependence on one commodity (oil), which carries within it greater risks than the benefits obtained as goods In spite of the GCC countries adopting economic development strategies and plans, they faced many obstacles due to various factors, notably the political factors associated with the IMF's proposals, which called for these countries to Seen by oil exporters faces a long-term challenge of reducing their dependence on oil as a single commodity

This is evidenced by the follow-up of GCC GDP indicators. In 2014, oil accounted for $90 \%$ of total GCC exports abroad, for example in Saudi Arabia to 86\%, and in Qatar to 94\% , 94\% in Kuwait, 84\% in Oman,

The issue of government spending in the Gulf Cooperation Council (GCC) states employs three areas: current, investment, and government lending to public institutions to ensure their continuity. These countries face pressures on the issue of unsustainable government spending. On basic resource subsidies such as fuel, electricity and other services, as well as the lack of a consumer culture in the use of state-subsidized resources (16)

The oil revenues are not used in the long term investments. The Gulf expenditure goes mostly to current and investment tunnels, as well as to the increasing tunnels on the security and military sectors, which in turn has placed a heavy burden on the budgets of the GCC countries

On the level of social challenges that pose a challenge of another kind, we can say:

The societal challenges have affected the structure of society in the GCC countries, and then the political systems of those countries. The marginalization of these forces and community groups within the framework of the Gulf structure 
In particular, the various social groups could have an impact on the stability of the internal system, as was the case with Islamic groups. In 1994, for example, Oman faced popular protests because of normalization with Israel. In the same context, social groups exerted great pressure on the Bahraini government, The Shiite community that was demanding their rights at the political, economic and social levels (17)

Therefore, the marginalization of these community forces can affect the security of the Gulf Cooperation Council by employing influential lobbying tools for the community forces towards the Gulf governments to change their policies either directly or indirectly, and in the absence of positive responses to those social variables may stimulate The international and regional forces to attract these elites of the community, which is naturally an added challenge facing the security of the Gulf Cooperation Council countries, as well as the failure of the Gulf governments to adopt balanced policies in this regard to absorb the magnitude of the reaction of the influential lobbying of those elites community

The issue of expatriate labor in the GCC has become a secondary problem in terms of societal challenges, especially after it has reached very high levels compared to the demographic composition of the Gulf States. This may stimulate the possibility of social, economic and political division between indigenous and expatriate citizens.

As a result of the emergence of a state of imbalance because of the semi-total dependence on the employment of the expatriate, which resulted in the aggravation of unemployment rates in the Gulf labor markets, which stimulates the negative effects of the unemployment problem in the GCC The national employment in the public sector, which absorbs more than $65 \%$ In addition, expatriate workers may pose security challenges that may pose a real threat to the stability of the GCC countries or may employ those expatriates from regional and international countries to play a stressful role in the region, posing a threat to security and stability

The challenges facing the GCC countries, which are based on security-military implications, can become direct threats if they are not genuinely addressed

The most important security-military challenges that have begun to threaten the security of the Gulf system have centered on sectarianism and the expansion of violent organizations in the region (18)

As well as the inability of the GCC countries to create a system of self-collective security to meet the security challenges - military in the future, so sectarianism and its negative employment leads to imbalance in the internal security structure of the Gulf Cooperation Council, which may be reflected in the growing political, economic and social differences of ethnic dimensions, This in itself represents the pattern of government policies to deal with popular demands, which is expressed by the continuity of the Shiite problem
In the three Gulf states Saudi Arabia, Bahrain and Kuwait there has been a disparity in the societal fusion between Sunnis and Shiites in the Gulf societies, so Sunni-Shiite tensions have emerged in certain areas, especially after the events of change in the Arab region in 2011, which may be cognitive stimuli for the production of direct threats that may effect On the Gulf security equation

Moreover, the GCC countries are unable to defend themselves and protect them militarily, which has made the Gulf States individually believe that the achievement of its security lies in the alliance with a superpower USA It is therefore very difficult for the GCC countries to build a collective military framework to carry out selfprotection tasks. They continued to rely on foreign military presence and to carry out maintenance work on their weapons and military systems, thereby weakening self-motivation in building the Gulf's own defensive and security capabilities. Mutual defense cooperation (19)

Especially if we know that the GCC countries lack, whether collectively or individually, the ability to develop a defensive strategy, due to several reasons, including that each GCC country has an awareness of the threat distinct from the other party's recognition, as well as weakness in the Coordination in terms of weapons systems and equipment, organization and training in the framework of strategic thinking, in each Gulf state there are weapons programs are different from each other, as the armament in some countries just a quantitative accumulation without the need for them technically or tactically

Which led to the disappearance of military thought in the Gulf countries in traditional frameworks, do not take into account the new military developments in military affairs, they are based on old organizations do not match the potential or quality of future wars

Moreover, the GCC countries have tended to use military force in the framework of regional interactions but to varying degrees in the framework of arming nonstate actors, especially when it comes to the use of force to achieve interests, leading to crises and conflicts, for example the use of forces The island's shield to intervene in Bahrain, and the use of military force in Yemen through the so-called Arab alliance, all these problems and challenges mentioned above will reflect the stability of the Gulf region in the future (20)

The third topic: a future vision for the security of the GCC countries

The review of a forward-looking vision that includes future prospects for the nature of internal challenges affecting the security of the GCC countries will be based on the projection of three future prospects according to the following pattern

The first possibility is the possibility of strengthening reforms at the level of the Gulf regimes. It can be assumed that the crystallization of one of the main responses to the security challenges of the GCC countries 
is based on the possibility of internal reforms within the systems and institutions of the Gulf states, whether at the level of internal systems or mechanisms of the Gulf Cooperation Council, To the possibility of upgrading from coordination to cooperation, which leads in a gradual context to integration in order to reach the stage of union among the GCC countries, as we can see a significant political development in the systems of the Gulf Cooperation Council( 21)

A number of factors contribute to motivating opportunities for this future possibility

1. The nature of external variables in the political, economic and social fields represented by the trends of democratic transformation, and mechanisms of global economic competition can constitute opportunities for the direction of change and reform.

2. Growing awareness of the importance of the concept of citizenship and strengthening within the framework of political construction of the Gulf States.

3. The availability of the political will to recognize the role of the Chaldean factions that demand political change within the framework of political reform in the GCC countries, which has emerged clearly in the movements of change in Kuwait, Bahrain and Saudi Arabia.

4.The existence of interests and threats common to stimulate the awareness of those countries to work on the development of joint strategies for the process of modernization and institutional renewal to raise the possibility of real reform in the GCC

Trends in the establishment of regional organizations in the context of the equation of economic competition may motivate the GCC countries to crystallize the data of this future possibility (22)

The second possibility: the possibility of the retreat of the GCC countries from reforming their political systems will lead to the weighting of the character rather than the cooperative in the framework of interrelationships that will lead to increased levels of tension and contradictions between the GCC countries.

Here we can examine the most important motivational drivers to predict the emergence of this future possibility as follows (23)

1. The increasing contradictions and family differences in the future, as the internal division is one of the most significant risks facing the Gulf political systems, and reinforced by the sharp divisions between the political elites of the new generation and old, and growing indices of competition between them to seize power.

2. Lack of political will based on activating the reform inputs to the Gulf systems and institutional frameworks to reach the production of outputs that are within the framework of promoting theses of democratic transformation.

3. Lack of effective and organized political opposition within the framework of political action, and the emergence of leaders and leaders of regional and family rather than party leaders.

4. The persistence of stagnation, the immaturity of institutional work and strengthen the possibilities of political reform and the roles of popular channels to influence the political systems of the Gulf Cooperation Council

Third possibility: the possibility of continuity of internal conditions related to the political systems of the Gulf Cooperation Council countries, and the lack of political reforms actually change the philosophy of the nature of government as this possibility focuses on the continuity of the Gulf regimes in their approach to survival on absolute rule, and the absence of dynamic shifts in the process of democratic transformation in the short and medium term for future studies, with the likelihood of survival potential conflict between the new generation of political elites and the old generation, which will have negative repercussions on the reality of political action in the GCC countries in the future

The most prominent indicators that reinforce the validity of theses of this future possibility (24)

1. Tribal, religious and family identities play an influential role within the framework of the Gulf society structure, giving political legitimacy to the nature of those Gulf regimes.

2. Lack of effective political organizations within the context of organized political opposition capable of bringing about changes in the level of the internal environment.

3. The interactions of the external factor related to the nature of the relationship between the United States and the Gulf Cooperation Council countries, despite the calls of the United States of America to the need for democratic political reforms, but find that alternative options are possible alternative will produce us violent currents

4. And this is not consistent with the nature and specificity of US interests with the GCC countries over the medium term, which allows crystallizing the variables of interactions of the internal environment of the Gulf.

5. The possibility of employing the economic capabilities possessed by the GCC countries to maintain the continuity of the status quo as it is without making fundamental changes in the level of the internal environment Gulf (25)

\section{Conclusion}

Through our research (The GCC Security Problem: A Study of Internal Challenges and Future Prospects), we have tried to gain a real understanding of the nature of the internal challenges facing the GCC countries and their prospects for the future. 
The GCC states have failed to create a common defense and security policy among their countries to protect their own security away from the polarization and influence of the external actor (USA) as a result of disagreement on reaching understandings on many issues and the possibility of achieving other objectives at different levels, Here we can summarize the reasons for this in the following

1. The disparities in capacities among the GCC countries and the inter-political differences among its members.

2. The lack of agreement on defining the nature of the challenges and threats facing the security of the GCC countries.

3. The GCC countries intersect in defining and defining the nature of the contemporary security challenges. There are many visions regarding the concepts of security. Some countries present the traditional military concept to the contemporary concepts of security, which have been thoroughly discussed in the first part of this research.

\section{Accordingly, we have reached the following conclusions}

1. GCC countries have faced a range of challenges above conventional and varying degrees and have become a source of threat to the Gulf regional security environment without a common framework for dealing with them.

2. The political challenges in the Gulf States are not limited to individual countries, but the entire Gulf region.

3.The differences and contradictions between the Gulf Cooperation Council countries extended to the scope of perceptions and capabilities and the main features of them, which led to the production of distrust between large and small countries in the context of the Gulf regional environment, the most significant sign of the recent crisis between Qatar on the one hand and Saudi Arabia, Which has contributed to strengthening the security of interactions between the GCC countries, leading to the emergence of perceptions and perceptions of perceptions that the threat to its security comes from within the Gulf environment and not from outside the scope.

4. The historical problems and differences on many issues, whether political or border problems, resulted in the lack of a common vision of many of the internal challenges that faced.

5. The failure of the GCC countries to achieve a unified economic development, and therefore continued to be unable to diversify their economic structures and find real alternatives to the revenues of petro-dollar revenues.

6 . The imbalance in the composition of the population between indigenous and expatriates, as a result of weak policies and legislation of the Gulf Cooperation Council countries, which contributed to the emergence of a range of challenges at the social level was itself another challenge.

7. The political differences and lack of crystallization perceptions of mistrust, and the specificity of the demographic environment among the GCC countries led to the failure to develop a defense policy - security common to the States, which constitute a positive balance in the face of internal challenges that may threaten the GCC countries in the future .

\section{References}

[1]. Mohammed Al-Said Idris, Regional System of the Arabian Gulf, Center for Arab Unity Studies, Beirut, 2000, pp. 182183.

[2]. Raymond Kaltah, Problems of Collective Security: The Reality of Challenges and Future Scenarios, Gulf Affairs, Issue 49, Gulf Center for Strategic Studies, London, 2007, pp. 85-86.

[3]. Gamal Mazloum, The Defense Capabilities of the Gulf Cooperation Council (GCC) 25 years after its establishment, Gulf Center for Strategic Studies, London, 2006, pp. 42-43

[4]. Mohammed Ezz Al-Arab, The Over-the-Counter Security Threats in the Gulf States, Strategic Papers, No. 261, AlAhram Center for Political and Strategic Studies, 2016, pp. 14-15.

[5]. Khalid Hanafi, The Limits Between the State and the Changes of the Region, Journal of International Politics, No. 201, Al-Ahram Center for Political and Strategic Studies, Cairo, 2015, pp. 3-4.

[6]. Anthony Cordesman, The Arab-US strategic partnership and the changing security balance in the Gulf, center for strategic and international studies, Washington, DC, 2015

[7]. Abdel Nour Antar, Evolution of the concept of security in international relations, Journal of International Politics, No. 160, Al-Ahram Center for Political and Strategic Studies, Cairo, 2005, pp. 89-90.

[8]. Ashraf Abdel Hamid Keshk, Regional Security Developments since 2003: A Study on the Impact of NATO Strategy, Center for Arab Unity Studies, Beirut, 2013, p13.

[9]. Graham Evans, Jeffrey Noinham, Penguin Dictionary of International Relations, translation: (Gulf Research Center), Jeddah, 2004, p. 494.

[10]. Riad Hamdouche, Evolution of the concept of security and security studies from the perspective of international relations, research presented to the International Forum (Algiers and the Mediterranean security, edited by Abdel Majid Qamouh, University of Constantinople, Algeria, 2008, pp. $279-280$

[11].Zakaria Hussein, National Security, www.politics-ar.com, $11 / 7 / 2018.11$

[12]. Nugdet Sabri, Ibid., P. 67. Nawar Mohammed Rabeeh AlKhairi, Trends in European Security after the Cold War: A Study in Atlantic and Mediterranean Security, Dissertation (unpublished), Baghdad University, Faculty of Political Science, 2001 , Pp. 23-24 .

[13]. Hassanin Tawfiq Ibrahim, Gulf Where? Outlook, Gulf 2014, Gulf Research Center, Dubai, 2005, pp. 257-259.

[14]. Lawrence Goss Potter, Introduction to Sectarian Politics in the Gulf Region, Summary Report of the Working Group, Center for International and Regional Studies, Georgetown University, Doha, 2015, pp. 1-2.

[15]. Aslam Khalid, Gulf-Gulf Differences: Causes and Issues, Solution Mechanisms, Al-Jazeera Center for Studies, www.studies. Aljazeera.net, 14/7/2018

[16]. The direction of security: the path of the Gulf inter-alliance, the Arab strategic report 2013-2014, Al-Ahram Center for Political and Strategic Studies, Cairo, 2015, pp. 229-230 
[17]. Qatari Foreign Minister Mohammed bin Abdul Rahman discusses the future of the Gulf Cooperation Council (GCC), Arab Television, London, June 30, 2017

[18]. Moataz Salameh, Gulf Arab Union Future Prospects, Journal of International Politics, No. 196, Al-Ahram Center for Political and Strategic Studies, Cairo, 2014, pp. 34-35.

[19]. GCC Interaction with the Arab Revolutionary Movement, Arab Strategic Report 2011-2012, Al-Ahram Center for Political and Strategic Studies, Cairo, 2013, pp. 156-157.

[20]. Ahmed Yahya, Gulf Cooperation Council Countries, The Internal Environment and Prospects for Reform, Gulf Affairs, Issue 49, Gulf Center for Strategic Studies, London, 2007, p. 68

[21]. Anwar Mohammed Gargash, The Need for Reform and Stability in the Arab Gulf Region, in the Arabian Gulf Between Conservatism and Change, UAE Center for Strategic Studies and Research, UAE, 2008, p 42.
[22]. Al-Rasheed, The Internal Stalemate in Saudi Arabia and the Regional Responses of the Arab Uprisings in a Group of Researchers, The New Middle East, Protest, Revolution and Chaos in the Arab World, edited by Fawaz Gerges, Center for Arab Unity Studies, Beirut, 2016, pp. 324-325.

[23]. Ali Khalifa Al-Kuwari, Towards a Future Vision to Strengthen Democratic Efforts, The Arab Future, No. 267, Center for Arab Studies, Beirut, 2001, pp. 21-22

[24]. Mohammed Ibrahim Mansour, Future Study: What is the importance and importance of Arabization, paper presented to the workshop on future studies within the activities of the Seventh Island Forum, Doha, 2013.

[25].Jamal Sanad Al Suwaidi, Global Strategic Developments: A Vision, 16th Annual Conference, Emirates Center for Strategic Studies and Research, March 21-23, 2011, pp. 7-8 